\title{
Protection for Trafficking Victims: The Perspectives of Law and Psychological Health
}

\author{
Sulistya Eviningrum ${ }^{1}$, Hartiwiningsih ${ }^{2}$, and Moh. Jamin ${ }^{3}$ \\ ${ }^{1}$ Doctoral of Law Student Universitas Sebelas Maret Surakarta, ${ }^{2}$ Professor of Law Universitas Sebelas Maret \\ Surakarta, ${ }^{3}$ Associate Professor Universitas Sebelas Maret Surakarta
}

\begin{abstract}
Human trafficking is a crime carried out by a dark society of some people, and its network is between countries and in international borders. Most victims come from developing countries. The main aim of this crime is to force young boys and girls to work in sexual sectors. There is economic oppression as they are exploited for the interests of the agents, distributors, and crime syndicates as what is similar to other illegal activities which regard trafficking, such as trafficking of domestic workers, fake marriage, illegal jobs, and illegal adoption. This research analyzes the legal protection for human trafficking victims and the health impacts. This is a doctrinal legal research, strengthened by the qualitative field research. It uses the constitutional and case approaches. Based on the results of the study and the discussion, it can be concluded that there are some impacts of the child trafficking in the aspects health and other aspects for the children. $T$ The government needs to formulate and to refine the constitutional regulations regarding the health protection for victims of child trafficking.
\end{abstract}

Keywords: Health impacts, legal impacts, child trafficking, protection, psychology.

\section{Introduction}

The phenomenon of child trafficking has long developed in countries such as Saudi Arabia, Japan, Malaysia, Hongkong, Taiwan, Singapore, and even Indonesia. No country is immune from trafficking. Each year, it is estimated that 600.000 until 800.000 men, women, and children are internationally trafficked for sexual exploitation ${ }^{1}$.

They use the threat of violence and even the violence itself. They kidnap, undergo fraud, forgery, and misuse of power and position. They give payments or benefits so that they receive the agreement of the people who have control of the victims ${ }^{2}$.

One of the urgencies of this child protection is encouraged by the understanding that children are

\section{Corresponding Author:}

Sulistya Eviningrum

Doctoral of Law Student Universitas Sebelas Maret

Surakarta

e-mail: eviningrumsulistya@yahoo.co.id still inherently and relatively weak in their growth and development processes $^{3}$. Even, if viewed from the victimological perspective, Finkelhor ${ }^{4}$ in his book entitled "Childhood Victimology" stated that children are human beings which are most prone to become victims of criminal activities in the society, not only the conventional crimes which target adults, but also specific crimes which happen only to children. Child trafficking is one of the worst actions of power experienced by women and children.

It is also a criminal action which is a violation of the human rights ${ }^{2}$. Human rights ignorance becomes very clear when relating to children and their rights. The violence against children is so massive that a lot of them become victims of child trafficking. There are tens of thousands of women under the age of 18 in Indonesia who wander day and night as sex commodities. On top of that, millions of Indonesian children are also forced to work improperly, such as becoming beggars, peddling newspapers on the streets or scavenging 5 .

Arif gives the definition that victims are those who suffer physically and mentally as a result of other 
people's actions who seek the fulfillment of their own interests or other people's, which is against the interests and the rights of the people who experience the loss ${ }^{6}$. The human trafficking issue often become the discussion topic in the field of legal studies and social studies. There has been quite enough interventions, policies and formulations of the constitutional regulations regarding this problem to minimize the case prevalence of the human trafficking in the future.

This is actually a very good thing, apart from the fact that there are legal aspects which handle this issue, it also proves to the society that human trafficking is a crucial issue which must be faced together. The cases of human trafficking often start from document fraud ${ }^{7}$.

The cases of sexual exploitation which happen in Indonesia increase by $30 \%$ each year. Victims of the commercial sexual exploitation to children are underage children who have high risks in being infected with diseases due to free sexual activities. From time to time, some opinions which relate the human trafficking with the issue of the human rights violation emerge. Starting from that time, new policies were issued, which start to pay attention to the aspect of the victims in human trafficking.

Some efforts have been carried out by the government, non-governmental organizations, and various social movements. These efforts include the preventive and controlling efforts in various situations where human trafficking is prone to happen. According to the statement the problem is how do the child sexual workers who are victims of human trafficking in a prostitution site assess the reproductive health and the psychological health?

\section{Research Method}

The method of this research is qualitative, using the case study design with the method of profound interview to some informants, which consist of children and guardians of children. This research aims to dig into the physical and health impacts of the trafficking victims. This research obtains information on the knowledge of the child informants regarding the physiology and the reproductive health. The victim suffered syphilis, or what they usually call kapatil. Meanwhile, about HIV/ AIDS, they believe that it is a disease which may be infected through the nose and mouth, and that to prevent oneself from being infected. They also suffers stress and trauma after the incident even after several years.

\section{Discussion}

There needs to be an adequate legal protection for crime victims, as it is not only a national issue, but also an international one ${ }^{8}$. Generally, prostitution is defined as someone's involvement in a sexual behavior or activity, in this case intercourse, with the aim to trade that activity with something else, usually in the form of some amount of money ${ }^{9}$. Even, the majority of the trafficking victims who were exploited sexually became pregnant, which leads them to undergo abortion. This condition often threatens their lives. Based on the Governmental Decree No. 16 of 2014 regarding Reproductive Health, abortion is a prohibited activity, and is only allowed in certain conditions, such as the indication of medical urgency, like a pregnancy which threatens the health of the mother and the fetus; pregnancy due to rape (it may only be carried out if the pregnancy age is at most 40 days from the first day of the last menstruation period).

This Governmental Decree regulates on how abortion may be done only in certain conditions, and how abortion is carried out safely with the help of doctors. With this Governmental Decree, it is hoped that abortion is no longer carried out carelessly. It is also to minimize the number of extramarital pregnancies or unwanted pregnancies ${ }^{10}$.

This is where the familial strength becomes an important thing, because it can give mental support to the victims. Quoting from an article, it is said that generally, a family has these functions: 1) Replacement of the population, the function to continue its offspring; 2) Care of the young, the function of caring for children; 3) Socialization of new members, the function to socialize cultural values, norms, and language to family members; 4) Regulation of social behavior, the function of regulating sexual behavior; 5) Source of affection, the function to give affection. Child trafficking is a phenomenon indicating that the family does not function well ${ }^{5}$. A similar thing was stated by Kramer as cited in Lehmiller ${ }^{11}$,where sexual workers suffer some diseases which regard the physical and the psychological condition.

From the numerous diseases they suffered, sexuallytransmitted diseases and HIV/AIDS are the categories which receive the highest attention, as they have the highest correlation towards the health of the sexual workers, in this case the reproductive and the sexual health ${ }^{12}$. Apart from that, the sexual workers are regarded as one of the mediators in the infection of that disease. 
The basic principles of the public health are promotive, preventive, curative, and rehabilitative, where this is certainly in line with the initiating movement which carry the background of the human rights approach ${ }^{13}$. Human trafficking may be regarded as a public issue, as it influences the social and the mental aspects of an individual, a family, and even the whole community of various generations. The many cases of human trafficking and the complexity of this issue makes the policy-makers face difficulties in finding the right method to prevent it.

Human trafficking is very worrying, but the crime increases with diverse modus operandi year by year. This is because the public still lacks of understanding of human trafficking. Moreover, the law enforcers often consider human trafficking as a common crime. On top of that, legal policy products are still unable to give attention to victims of trafficking ${ }^{5}$.

In Indonesia, prostitution is regarded as a morality/ decency crime, and it is an illegal activity which violates the law. In the ratification of the Republic of Indonesia's Constitution No. 7 of 1984, women trafficking and prostitution is regarded as violence towards women. Prostitutes are workers who turn themselves in, who sell the service of carrying out sexual activities to the public, and receiving payment according to the initial agreement. Prostitution is the sale of sexual services, such as oral sex or sexual intercourse. Someone who sells the sexual services are called prostitutes or what is usually called commercial sexual workers. The activity of prostitution is an activity which must be regarded as taboo, as it is morally contradictory to the values, religion, and norms. Prostitution is one of the social problems which raises concerns.

There are many factors which cause prostitution to be part of a child's life. One of them is the low knowledge of the child on prostitution. Apart from that, important factors include the lack of attention from parents, lesbianism which is visible in a woman, the influence of alcohol, the reading materials of children on prostitution, and even the current sophisticated communication technology. The most influencing result of this social problem is the increase of unwanted pregnancies ${ }^{14}$.

According to the World Health Organization ${ }^{15}$, there are some health and other impacts of human trafficking to the human beings. These are the impacts which results from the human trafficking cases: The victim's terrible mental health condition is the dominant health effect and it clearly brings loss. The psychological consequences include: depression, post-traumatic stress disorder, and other anxiety disorders; thoughts of suicide; and somatic conditions including physical disfunction.

The victims are socially isolated. For example, they are prohibited from contacting their families, and their space for mobility is also restricted. This is used to maintain the power over the children in a trafficking condition, such as emotional manipulation using threats and empty promises.

The victims are also exploited economically. The children who are sold do not have the power to make decisions of what they can do. They are not paid for their services. Even, the traffickers may impose fees to the victims for housing, clothes, food, or transportation.

There is a legal insecurity for the people who undergo interborder travel, especially when the trafficker or the illegal business owner confiscate the identification documents, or if they give fake information regarding their rights, including regarding the access to health services. This condition does not only limit the society's use of the health facilities. Yet, it may also cause unjust deportation or imprisonment. It is impossible for the trafficked victim to be regarded as crime victims. Unfortunately, they are regarded as violators of migration regulations, workers or prostitutes who are against the law. They may be imprisoned in the correctional centers or imprisoned as illegal immigrants. When they come back home, the trafficking victims may have the same trouble as when they were trafficked overseas. Plus, they must deal with new health problems and other challenges, including stigma and psychological problems. Meanwhile, for the children who try to stay in that location, they often face discomfort or pressures.

In the first three months of 2019, the Indonesian Commission for Women and Children has supervised and watched over eight cases. The ones which stand out are handled by the police force. The cases are spread out almost evenly in all parts of Indonesia, with the average number of three victims in each case. On January, five children were involved in a storefront sex prostitution in Bali, as stated by Solihah, Commissioner of Child Trafficking and Exploitation, the Indonesian Commission for Women and Children), in Menteng, Central Jakarta, March 29 2019.

Based on the results of study, $30 \%-87,8 \%$ of 
victims accessed health services during the period of exploitation. Most of them are illegal workers or blue-collar workers, children, and women. We know that there are risk factors, signs, and symptoms ${ }^{16}$ of a trafficking case. In the efforts to make the medical aspect as one of the keys in developing the identification tool of human trafficking, the health workers must be equipped with the knowledge that the risk factors which exist in a population do not always indicate that human trafficking is happening ${ }^{17}$. But, the increasing risk factors of a population may cause that population to become prone to human trafficking.

The symptoms which are found during the anamnesis period or the physical examination may become an indicator that human trafficking has happened or is happening. These signs and symptoms may be in the form of sexually transmitted diseases which are not treated, the patients do not know where they are, there are abnormal physical wounds, and when the patients come, they are accompanied by someone who has the tendency to be dominating during the anamnesis process between the patients and the doctors. The existence of these signs and symptoms must lead to interventions from some parties. Yet, it is unfortunate that there are not enough trainings on this case from the various sectors (the medical, legal, and social sectors). This causes the loss of the signs and symptoms which may identify trafficking, which may then lead to an intervention from the health workers.

Other studies also found that the trafficking victims tend to open up more to health workers as opposed to police officers. This strengthens the fact that the medical sector has a unique position to identify these signs and symptoms and treat them. Even though the trafficking victims are regarded as a hidden population due to the complexity of this issue, as it is connected to criminality and violation of rights by the regulation policies which are currently developed, yet at some point of time, these victims will interact with the outside world through the medical sector. Because of that, the existence of the trafficking signs and symptoms may become the ideal intervention point to initiate an identification and further services.

\section{Conclusion}

The victim's terrible mental health condition is the dominant health effect and it clearly brings loss. The psychological consequences include: depression, post- traumatic stress disorder, and other anxiety disorders; thoughts of suicide; and somatic conditions including physical disfunction. Victim need a social, health and psychological care to recover their physical and psychological health. The collaboration between the public health discipline and the medical aspect carried out by the doctors and nurses in hospitals, private clinics, and other medical service offices may become the new holistic solution in handling the human trafficking problem.

\section{Conflict of Interest: No}

\section{Source of Funding: Author}

Ethical Clearance: Yes

\section{References}

1. Purwawidada F. Perdagangan orang sebagaitindakkejahatantransnasional (Human trafficking as a transnational crime).2015.

2. AbdullahD. The policy of criminal law in preventing and handling the women and children trafficking crime study at the political territory of Banyumas [postgraduate thesis]. Purwokerto: Unseod; 2010. 1 p.

3. Rhona KM,Smith.Hukumhakasasimanusia (The human rights law). Yogyakarta: Pusham UII; 2010

4. FinkelhorD. Childhood victimization. New York: Oxford University Press; 2008.

5. Eviningrum S. Strengthening human rights-based legal protection on victims of child trafficking in Indonesia.Int.J. of Advanced Science and Technology. 2019;28(20):296-300.

6. MintarsihFM.Upayaperlindungan korban terhadapperdaganganperempuandi Indonesia (The effort of women trafficking victim protection in Indonesia. J.MimbarllmiahHukumUniversitas Islam Indonesia. 2007:7.

7. Melisa H. Human trafficking cases often start with document fraud [Internet]. East Java: Detik News; 2019 [cited 2019 Sep 26]. Available from: https://news.detik.com/ berita-jawa-timur/d-4645074/kasus-humantrafficking-kerap-diawali-pemalsuan-dokumen? $\mathrm{ga}=2.223534299 .1153676289 .1569447200$ 775392883.1566273770 .

8. Ifrani. Disharmony in the management of forest areas in Indonesia. J. Hukum Al'Adl. 2015 Jul-Dec 14;7:89. 
9. Nazemi N. Legalizing prostitution means legitimizing human rights violation.Int.J. of Humanities and Social Science.2011;1(9):114-120.

10. Veratamala A. (2020). Berbagairisiko yang mungkintimbulakibataborsi (The many risks which may happen due to abortion) [Internet]. Hello Sehat; 2019 [cited 2019 Sep 25]. Available from: https:/hellosehat.com/kehamilan/melahirkan/ berbagai-bahaya-aborsi-ilegal/.

11. Lehmiller JJ. The psychology of human sexuality. Singapore: John Wiley \& Son; 2014.

12. Alexander P. Sex work and health: a question of safety in the workplace. JAMWA.2008;53(2):77-82.

13. Zimmerman $\mathrm{C}$, Hossain MCW. Human trafficking and health: a conceptual model to inform policy, intervention and research. Social Science \& Medicine. 2011:351.
14. Suharyanto A. Dampakprostitutsibagikesehatan mental wanita (The impacts of prostitution towards the mental health of women) [Internet]. DosenPsikologi; 2019 [cited 2019 Sep 25]. Available from: https://dosenpsikologi.com/ dampak-prostitusi-bagi-kesehatan-mental-wanita

15. WHO. Understanding and addressing violence against women: human trafficking [Internet]. The World Health Organization; 2019[cited 2019 Sep 26]. Available from: http://apps.who.int/iris/ bitstream/10665/77394/1/WHO_RHR_12.42_eng. pdf.

16. Stewart D. Trafficking and Health. 2013.

17. ZimmermanC. Health risks and consequences of trafficked women in Europe: conceptual models, qualitative and quantitative findings. London: London School of Hygiene and Tropical Medicine; 2007. 